\section{Devil of a business}

\section{Anthony Sampson}

Fundamentals of the Petroleum Industry. By Robert O. Anderson. Weidenfeld \& Nicolson/University of Oklahoma Press: 1985. Pp. 390. £18.95, \$29.95.

ROBERT Anderson's Fundamentals of the Petroleum Industry, lavishly printed and illustrated, is clearly designed to be a standard guide to the oil business - a successor to an earlier book of the same title by Dorsey Hager. Much of it is a description, in clear and upretentious language, of the basic engineering and organization of the oil business, including the geology, drilling, transport and refining. But it has the added interest of being written by one of the most successful, and wealthiest, practitioners in the industry. Anderson made a fortune as an oil entrepreneur in New Mexico, which he then extended as chairman of Atlantic Richfield based in Los Angeles.

Atlantic Richfield (Arco) has been one of the most aggressive and well-managed rivals to the traditional muiltinational oil companies, the "seven sisters"; and Anderson himself claims (with some exaggeration) that Arco is "often regarded as the Eighth Sister". But certainly the company has had a remarkable record in exploration and development - above all in

\section{MONOGRAPHS TEXTBOOKS...}

\section{and other technical publications on Nuclear Energy}

\section{write for free publications and services catalog}

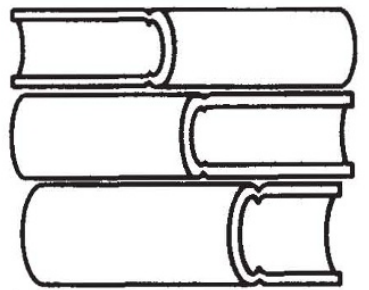

American Nuclear Society $555 \mathrm{~N}$. Kensington Ave. La Grange Park, IL 60525 (312) 352-6611

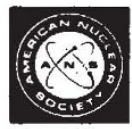

Reader Service No.6 finding oil in Alaska - which adds authority to the book's technical chapters.

Anderson is financier as much as an oilman, and knows full well that oil is increasingly a business "of partnerships and shareholders, bankers and backers". So while the book provides a readable beginner's guide to the industry's workings, complete with diagrams, graphs and a glossary, it also includes financial and political judgements which have a wider interest.

Predictably Anderson is a champion of free enterprise in oil: governments, he says, "do not have the pressures, the energies, the tempo, the dynamics of the private sector"; the speed of drilling in Russia, for instance, is five to ten times slower than in North America. He explains with natural certainty that in the oil business "there was, and is, still room for individuals with friends, faith, perseverance, some money, and a lot of luck to become independently wealthy", but is less convincing when he asks: "who then owns the petroleum industry? Its customers and employers do, in a very real sense. And who pays for it? The very same". In similar vein he is critical of many government attempts to regulate and control his industry, which he sees as the only one with the resources to develop alternative energy sources.

Anderson, however, is also a realist: he recognizes that outside the United States governments will insist on having their own oil corporations and controls, and concedes that even in America the "invisible hand" of free enterprise may not be enough: "if even the gentlemanly game of tennis must have umpires, referees and linesmen, then how much more so must the game of capitalism have them, where the stakes are so high?".

The early chapters provide a rapid history of oil since its discovery in Pennsylvania, re-telling familiar stories about wildcatters, gamblers and monopolists with some marvellous old photographs but no obvious new research. Rather, it is the assessment of the recent past and the future which is most useful.

Anderson points out that "learned people have been predicting the exhaustion of the world's oil since 1863" and how "the day of reckoning has always seemed to be about twenty years in the future. Somehow, a new series of major discoveries has always put off that day". Will that postponement continue? The forecasts remain very divergent, both about future production and consumption. For the time being, as Anderson describes it. the Organization of Petroleum Exporting Countries (OPEC) can fix a price which is low enough to keep most new alternative energy - whether tar-sands, solar energy or windmills - uncompetitive with oil. But most experts, including Anderson, believe that before long oil shortage will push up the oil price above the equivalent for new forms of energy:
At the crossover time, probably in the 1990 s [says Anderson], the combined productive capacity of all conventional sources. including OPEC. will no longer equal demand at a price OPEC can influence. Demand will pull prices up, and no producer will have the power to depress them.

Forecasts of the price of oil have been notoriously unreliable: even since Anderson finished this book - two years ago; it was published in the United States in 1984 - the Western consumption of oil has diminished and new oilfields have been found, pushing back the likely date of that crossover. The day of reckoning may still be about 20 years ahead, but it cannot be postponed much further.

The future control of oil is very uncertain. Mr Anderson's historical chapters

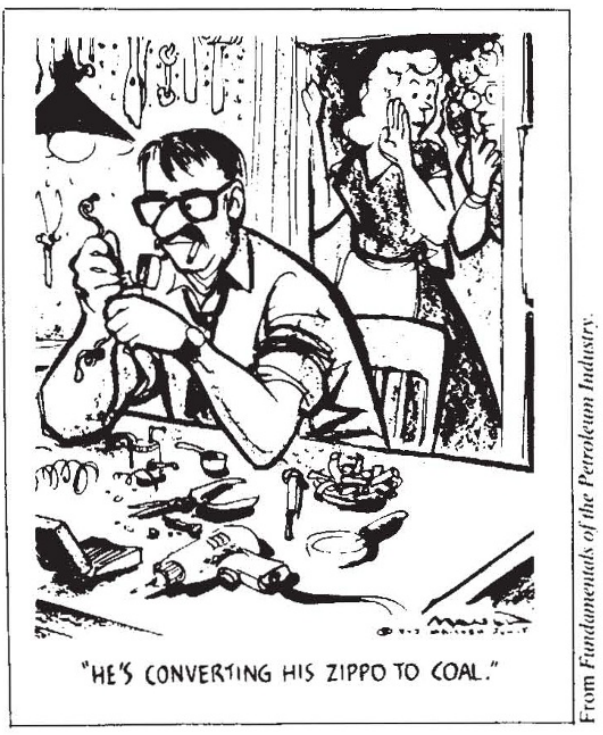

1973 - time of another oil crisis.

vividly describe the extraordinary alternations of glut and shortage in the past, which caused crazy oscillations in the oilprice until production was effectively controlled - whether by Rockefeller, or by the Texas government. or by the Seven Sisters, or by OPEC. For the foreseeable future he believes (or believed in 1983) that OPEC will be "a major influence on world supplies and world market prices". Other oil-producers outside OPEC will consume all they produce. But the new era of alternative energy should produce a world market which will be less dependent on the notoriously slippery behaviour of the oil-price.

Or will it? Anderson's clear exposition of the remorseless logic of world energy can be misleading. For behind all that intricate engineering and global organization oil has kept on playing tricks which have often made fools of experts and bankrupted rational corporations. As the Mexicans say: "God gave us the land, the devil gave us the oil".

Anthony Sampson, 27 Ladbroke Grove, London W11 $2 A Y, U K$, is author of The Seven Sisters: The Great Oil Companies and the World they Shaped (Hodder \& Stoughton, 1975). 